\section{Lysyy A., Ivanov 0. , Kotenko V.}

\title{
INVESTIGATION OF THE VARIABILITY OF LOCAL ICE STRENGTH BY EXPOSURE TO THE SPECTRUM OF INFRARED RADIATION OF VARIOUS LENGTHS
}

Об'єктом дослідження є взаємодія спектру інфрачервоного випромінювання з льодом. Робота була спрямована на визначення чієі взаємодії для можливості безпечного проходження маршруту судами льодового класу самостійно або в складі каравану в період зимової навігації, в замерзаючих акваторіях неарктичних морів і річок, плановано і без затримок. Для вирішення ивого завдання в ході дослідження використовувалися коефіцієнти подібності, рівні розрахованим, $і$ визначалися температурні інтервали, відповідні обраним дискретним інтервалам товщини льоду. Обробка даних лабораторних випробувань зводилася до статистичного аналізу, метою якого є визначення статистичних характеристик досліджуваних величин. А також встановлення кореляційних зв'язків між досліджуваними величинами і оцінкою значень мічності льоду малої забезпеченості. Це пов'язано з метою встановлення регресивних залежностей, що пов'язують межі міцності льоду і його температуру, солоність, а також щільність. Для вирішення аналогічної задачі різними науковими групами проводилися натурні дослідження і випробування криголамом «Діксон» (Росія) з різання льоду струменем температурно-активованої води або лазерним випромінюванням потужністю від 30 до 200 кBт, яке передається по оптико-волоконному кабелю.

У порівнянні з розглянутими способами, які мають недоліки в наступному:

- мобільність пристроїв;

- вага пристроїв;

- безперебійне забезпечення випромінювача досить великою потужністю протягом невизначеного часу;

- отримання киплячої води, яка утворюється при лазерному різанні льоду, що, в свою чергу, при низьких зовнішніх температурах повітря забезпечує швидке зрощення місия розрізу, яке стає набагато міцніше;

- порізані лазером шматки льоду в межах каналу будуть йти під судно. При наявності малих глибин це може зупинити рух судна або створити загрозу пошкодження корпусу судна. Завдяки результатам досліджень є можливим створення експериментальної самохідної автоматизованої установки для руйнування льоду замерзаючих акваторій і на підхідних каналах до порту, яка дозволяє:

- на першому етапі роботи раз'мягчати лід;

- на другому - його різати;

- на третвому етапі - перетворювати його в воду.

Ключові слова: зимова навігація, інфрачервоне випромінювання, спектр поглинання льоду, прохідність судів, лазерне різання льоду.

Received date: 06.11.2018

Accepted date: 21.11.2018

Published date: 30.06 .2019
Copyright (C) 2019, Lysyy A., Ivanov O., Kotenko V. This is an open access article under the CC BY license (http://creativecommons.org/licenses/by/4.0)

\section{Introduction}

The ice situation in the eastern part of the Black and Azov Seas (Ukraine) lasts from three to five months a year. The experience of independent navigation of ships and ice pilotage of ship caravans at that time showed a very high percentage of damage to ship hulls as a result of ice movements and ice compression [1]. Due to such circumstances, navigation safety is not guaranteed, and ice navigation becomes risky. The results of studies on the possible use of various technical means for piloting and facilitating the navigation of ships in ice conditions are presented in many published scientific papers, for example, in [2-4]. But experiments conducted by the authors of these works do not take into account shallow depths and ice movement. Therefore, it is relevant to conduct research aimed at ensuring independent navigation of vessels and as part of ship caravans in the Azov Sea and in the coastal eastern regions of the Black Sea. Thus, the object of research is the effect of infrared radiation of different wavelengths on ice. And the aim of the first stage of the work is studying the temperature distribution in the ice section when it is irradiated with infrared radiation with different wavelengths.

\section{Methods of research}

In the laboratory, mercury laboratory thermometers with a scale of $0.2{ }^{\circ} \mathrm{C}$ were installed in the interior of the frozen ice. When ice was irradiated with infrared radiation 
with a different wavelength coming from a manufactured adjustable infrared device, the temperature was recorded on each thermometer depending on the exposure time and the temperature of the source of the infrared emitter.

\section{Research results and discussion}

The readings of the above thermometers are entered in Tables 1-10.

As a result of the analysis of the obtained data, changes were found in the optical and mechanical properties of ice, worsening its strength characteristics, both on the surface and inside (Fig. 1). It was also found that the speed of ice melting when exposed to infrared radiation is insufficient for the passage of a vessel in ice with a given speed. Therefore, in addition to the effects of infrared radiation, softening the ice, it is necessary to investigate the installation of its mechanical grinding and melting. Taking into account the fact that the resistance of ice to a slice has the smallest parameter (Table 1), it is most advisable to study a mechanical device operating on a slice, determining the optimal speed of rotation and cutting of ice. Since this parameter is functionally related to the speed of the vessel in ice (2-3 knots). In the considered option, the method and a special manipulator device are studied in a laboratory, which will work in tandem with the vessel for its safe passage in the places of formation of hummock, solid and drifting ice with a thickness of $0.4-0.5 \mathrm{~m}$. When the ice thickness is exceeded more than 10-15 see, a remotely controlled manipulator device is lowered onto the ice and moving along a given route carries out thermal destruction of the internal part of the ice by infrared radiation $(\lambda=4 \mu \mathrm{m})$. At the same time, it crushes it with a special rotating and cutting ice device with cutters, reducing ice loads on the ship's hull and ensuring a safe possible speed of the ship (2-3 knots) along the laid route. Rapid melting of crushed ice at low ambient temperatures and an increase in the time it is in the unfrozen state is ensured by an additional infrared emitter with $\lambda=3 \mu \mathrm{m}$, located behind a special rotating device. Also, this emitter prevents an increase in ice hardness upon repeated freezing of crushed ice.

Since the resistance of the ice to the slice is approximately 2 times less than the rupture and 4 times less than the crushing [5] (Table 1), it is most advisable to consider and investigate the device working on the slice and determine the optimal speed for cutting ice. This parameter is functionally related to the speed of the vessel, the relief of the true thickness of the ice, and the relief of the temperature field of the ice cover [6].

Table 1

Some properties of ice

\begin{tabular}{|c|c|c|}
\hline Resistance property & Value, $\mathrm{MN} / \mathrm{m}^{2}$ & Note \\
\hline Crush & 2.5 & Polycrystalline ice \\
\hline Tensile & 1.11 & Polycrystalline ice \\
\hline Cut & 0.57 & Polycrystalline ice \\
\hline
\end{tabular}

At the first stage of the experiment, studies were carried out on the interaction of the infrared radiation spectrum on ice. According to the Wien formula [7], a temperature range was determined and an adjustable installation of radiant energy was made. Such a setting has a black factor close to unity. This means that most of the thermal energy is converted into a stream of electromagnetic waves [8]. The flow of electromagnetic radiation from a distance of $200 \mathrm{~m}$ was directed onto the ice plane, the wavelength changed and with the help of mercury laboratory thermometers the temperature was recorded in four places evenly separated from each other by thermometers.

The results are shown in Tables $2-10$, and the temperature distribution in the ice section upon irradiation with infrared rays is shown in Fig. 1.

Table 2

Initial values (distance between thermometers - $4 \times 30 \mathrm{~mm}$; immersion depth of laboratory mercury thermometers - $100 \mathrm{~mm}$; distance from the emitter to ice - $200 \mathrm{~mm}$; ambient temperature $-22^{\circ} \mathrm{C}$; ice sizes - 200×200×300 mm; time - 12:30)

\begin{tabular}{|l|c|c|c|c|}
\hline No. of thermometer & T1 & T2 & T3 & T4 \\
\hline Temperature, ${ }^{\circ} \mathrm{C}$ & -4 & -5.2 & -5.7 & -3 \\
\hline
\end{tabular}

Table 3

The initial temperature in the inner section of the ice (time - 13:25)

\begin{tabular}{|l|c|c|c|c|}
\hline No. of thermometer & T1 & T2 & T3 & T4 \\
\hline Temperature, ${ }^{\circ} \mathrm{C}$ & -1.5 & -2.0 & -2.0 & -2.0 \\
\hline
\end{tabular}

Table 4

The steady temperature of ice in the laboratory (turn-on time - 13:30; temperature measurement time - 13:48; current - $2.2 \mathrm{~A}$; voltage - $100 \mathrm{~V}$; emitter temperature $\left.-350^{\circ} \mathrm{C}\right)$

\begin{tabular}{|l|c|c|c|c|}
\hline No. of thermometer & T1 & T2 & T3 & T4 \\
\hline Temperature at 13:30, ${ }^{\circ} \mathrm{C}$ & -1.4 & -0.5 & -1.8 & -1.8 \\
\hline Temperature at 13:48, ${ }^{\circ} \mathrm{C}$ & -1.3 & -0.5 & -1.7 & -1.6 \\
\hline
\end{tabular}

Tahle 5

The temperature of the ice in the laboratory after turning on the infrared emitter at the values: time - 14:05; current - $2.3 \mathrm{~A}$; voltage $-105 \mathrm{~V}$; radiation temperature $-350-400{ }^{\circ} \mathrm{C}$

\begin{tabular}{|l|c|c|c|c|}
\hline No. of thermometer & T1 & T2 & T3 & T4 \\
\hline Temperature $-350^{\circ} \mathrm{C}$ & -0.5 & -1 & -1.5 & -1.5 \\
\hline Temperature $-400^{\circ} \mathrm{C}$ & -0.2 & -1.2 & -0.9 & -1.3 \\
\hline
\end{tabular}

Table 6

The temperature of the ice in the laboratory after turning on the infrared emitter at the values: time $-14: 15$; current $-2.4 \mathrm{~A}$; voltage $-110 \mathrm{~V}$; radiation temperature $-450{ }^{\circ} \mathrm{C}$

\begin{tabular}{|l|c|c|c|c|}
\hline No. of thermometer & T1 & T2 & T3 & T4 \\
\hline Temperature, ${ }^{\circ} \mathrm{C}$ & -0.2 & -1.2 & -1.2 & -1.4 \\
\hline
\end{tabular}

Table 7

The temperature of the ice in the laboratory after turning on the infrared emitter at the values: time $-14: 18$; current $-2.3 \mathrm{~A}$; voltage $-105 \mathrm{~V}$; radiation temperature $-400^{\circ} \mathrm{C}$

\begin{tabular}{|l|c|c|c|c|}
\hline No. of thermometer & T1 & T2 & T3 & T4 \\
\hline Temperature, ${ }^{\circ} \mathrm{C}$ & -0.2 & -1.2 & -1.2 & -1.4 \\
\hline
\end{tabular}


Table 8

The temperature of the ice in the laboratory after turning on the infrared emitter at the values: time - 14:22; current $-1.7 \mathrm{~A}$; voltage $-88 \mathrm{~V}$; radiation temperature $-350{ }^{\circ} \mathrm{C}$

\begin{tabular}{|l|c|c|c|c|}
\hline No. of thermometer & $\mathrm{T} 1$ & $\mathrm{~T} 2$ & $\mathrm{~T} 3$ & $\mathrm{~T} 4$ \\
\hline Temperature, $^{\circ} \mathrm{C}$ & -0.4 & -1.2 & -1.2 & -1.4 \\
\hline
\end{tabular}

Table 9

The temperature of the ice in the laboratory after turning on the infrared emitter at the values: time - 14:26; current $-2.6 \mathrm{~A}$; voltage $-78 \mathrm{~V}$; radiation temperature $-300^{\circ} \mathrm{C}$

\begin{tabular}{|l|c|c|c|c|}
\hline No. of thermometer & T1 & T2 & T3 & T4 \\
\hline Temperature, ${ }^{\circ} \mathrm{C}$ & -0.4 & -1.1 & -0.4 & -1.4 \\
\hline
\end{tabular}

Tahle 10

The temperature of the ice in the laboratory after turning on the infrared emitter at the values: time - 14:30; current $-0.95 \mathrm{~A}$; voltage $-60 \mathrm{~V}$; radiation temperature $-200^{\circ} \mathrm{C}$

\begin{tabular}{|l|c|c|c|c|}
\hline No. of thermometer & T1 & T2 & T3 & T4 \\
\hline Temperature, $^{\circ} \mathrm{C}$ & -0.3 & -1.2 & -0.3 & -1.3 \\
\hline
\end{tabular}

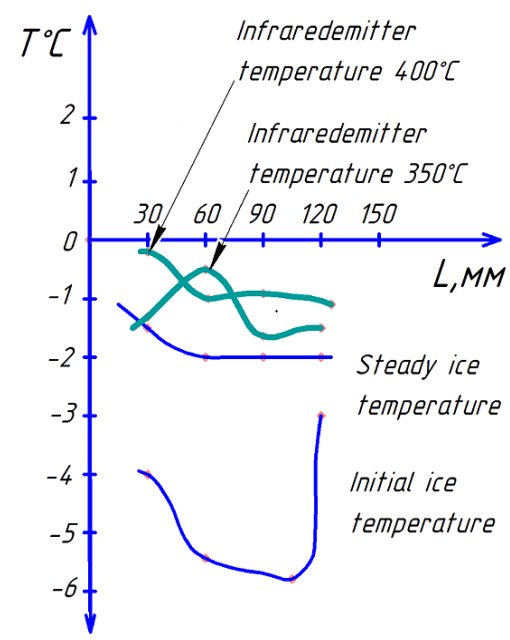

Fig. 1. A graph of the temperature distribution in the ice section when irradiated with infrared radiation ( $L$ - the distance between the thermometers, $T$ - the temperature on the thermometers)

Modern remote systems give only averaged readings using sequential comparisons of image signals using a variety of standards [9]. Given the fact that the skipper in order to decide on the use of this device needs to know the thickness of the ice, it becomes possible to conduct full-scale studies of the device to determine the thickness of the ice [10].

\section{Conclusions}

In the course of the study, it was determined that the transparency of ice clearly varies depending on the change in the wavelength of electromagnetic radiation, which penetrates deep into the ice and is effectively absorbed by it, increasing the temperature inside the ice. Clean air does not absorb infrared rays, and water absorbs all radiant energy in a very thin layer and its temperature is higher than the temperature of ice. A shorter wavelength with greater heating is opaque to ice and radiation energy is released on the ice surface. The peak of transparency in ice is in the region of $4-6 \mu \mathrm{m}$. In this range, the inside of the ice softens. The softened inner part of the ice will reduce the load on the electric drive, and the choppers of the grinder, eliminating freezing and speeding up the passage of the vessel along the laid path.

The research results will be useful when conducting full-scale tests during the ice navigation period to determine preliminary data on the ice parameters of the navigation area and to calculate the true thickness of the ice relief and the relief of the temperature field of the ice cover [11].

\section{References}

1. Lysyi, A. O. (2017). Zabezpechennia bezpechnoi lodovoi navihatsii na kanalakh Azovskoho moria. Visnyk Natsionalnoho tekhnichnoho universytetu «KhPI». Seriia: Mekhaniko-tekhnolohichni systemy ta kompleksy, 20 (1242), 25-29.

2. Svistunov, B. I., Ionov, B. P., Ilchuk, A. N. (1981). Issledovaniia raboty ledokola s sistemoi pnevmoobmyva (POU) pri forsirovanii torosistykh ldov. Trudy AANII, 376, 85-87.

3. Coi, L. G. (1982). Diagramma dlia opredeleniia skorosti dvizheniia sudov v ledovykh kanalakh. Sbornik nauchnykh trudov CNIIMF, 275, 67-72.

4. Bekker, A. T., Tsuprik, V. G. (2016). Energy Concept for Determining Ice Strength in Calculation of Ice Load on Vertical Offshore Structures. The 26th International Ocean and Polar Engineering Conference. Rhodes. Available at: https:// www.researchgate.net/publication/306357423_Energy_Concept_ for Determining Ice Strength in Calculation of Ice Load on_Vertical_Offshore_Structures

5. Petrov, I. T. (1976). Vybor naibolee veroiatnykh znachenii mekhanicheskikh kharakteristik lda. Trudy AANII, 331, 4-41.

6. Warren, S. G., Brandt, R. E., Grenfell, T. C. (2006). Visible and near-ultraviolet absorption spectrum of ice from transmission of solar radiation into snow. Applied Optics, 45 (21), 5320. doi: http://doi.org/10.1364/ao.45.005320

7. Derebere, M. (1959). Prakticheskoe primenenie infrakrasnykh luchei. Moscow: Gosenergo, 440.

8. Yu, Y., Rothrock, D. A. (1996). Thin ice thickness from satellite thermal imagery. Journal of Geophysical Research: Oceans, 101 (C11), 25753-25766. doi: http://doi.org/10.1029/96jc02242

9. Habruk, R. (2017). Analiz mizhnarodnykh ta vitchyznianykh standartiv lodovykh katehorii dlia zdiisnennia bezpechnoi navihatsii v akvatorii shelfu Ukrainy. Metrolohiia ta prylady, 5, 69-72.

10. Tronin, V. A. (1978). Rezultaty ispytanii ledovykh kachestv ledokolnykh buksirov. Teoriia $i$ prochnost ledokolnogo korablia. Gorkii, 9-12.

11. Sazonov, K. E., Starovoitov, O. M. (1989). Buksirovochnye ispytaniia etalonnoi modeli MKOB v ledovom opytovom basseine. Sudostroitelnaia promyshlennost. Seriia: Proektirovanie sudov, 12, 42-47.

Lysyy Andrey, PhD, Associate Professor, Head of Department of Navigation and Handling Ship, Azov Maritime Institute National University «Odessa Maritime Academy», Mariupol, Ukraine, ORCID: http://orcid.org/0000-0002-5596-0856,e-mail: anlis@ami.edu.ua

Ivanov Oleksander, Senior Lecturer, Department of Navigation and Handling Ship, Azov Maritime Institute National University «Odessa Maritime Academy», Mariupol, Ukraine, ORCID: http:// orcid.org/0000-0001-6992-0698,e-mail: kafnavigation@ami.edu.ua

Kotenko Vitaliy, Postgraduate Student, Department of Navigation and Handling Ship, Azov Maritime Institute National University «Odessa Maritime Academy», Mariupol, Ukraine, ORCID: http:// orcid.org/0000-0002-3044-7570, e-mail: dogyua@gmail.com 